\title{
A Christmas Carol by Charles Dickens: An Authentic Didactic Source for English Language Acquisition and Moral Value Teaching
}

\author{
RaIph OBANDJA BOYO \\ École Normale Supérieure
}

\begin{abstract}
In the language acquisition and teaching-learning process, the use of good and authentic didactic sources in the classroom is a prerequisite to help students develop language skills efficiently. The choice of these materials may be made based on engaging, interesting, and motivating themes aiming at developing students' awareness. In the same vein, this project has been designed to suggest Charles Dickens's A Christmas Carol as a teaching tool that can help students not only improve their linguistic competences, but also build their character. In other words, English Language Teaching and morality are inseparable and should be taught in the classroom.
\end{abstract}

KEYWORDS: A Christmas Carol, Authentic material, Language Acquisition.

\section{INTRODUCTION}

In Gabon, teachers use various didactic sources to teach English in their classrooms for more communicative purposes. They teach situational and functional language contexts for their learners to face daily situations. Teachers thus emphasize not only the improvement of the four skills (reading, listening, speaking, and writing) but also the language aspects (such grammar, vocabulary, and pronunciation).

However, the teaching and learning of English language should not exclusively be oriented to communicative and linguistic competences. It should go far beyond communication and language learning. Because today's learners are the hope of tomorrow, foreign language teachers should play a substantial role in their learners' moral development. The role of the English teacher should also be to combine the acquisition of the language with the teaching of human principles. In this perspective, learners could practice the language and build their personality. Such an endeavour consists in introducing A Christmas Carol by the British novelist Charles Dickens in the process of language acquisition and moral values transmission. The book tells the story of Ebenezer Scrooge, the main character, who happens to be rich but miserly and selfish towards his Victorian fellow citizens. Fortunately, thanks to nightly visits by four ghosts, his cold and insensitive demeanor will give way to pure kindness at the end of the novella. The book is an authentic material that covers a wide range of moral principles, which could be explored from selected texts. That didactic source will help the students improve not only the four basic skills but also encourage the construction of a positive psychological mindset.

Considering the above statements, the problematic of our research can be formulated as follows: how can a Christmas Carol by Charles Dickens enable learners' English language acquisition and moral value teaching? We hypothesize that $A$ Christmas Carol might facilitate English language acquisition and inculcate moral values in students through a set of thematic contents and interactional activities aimed at putting the learner at the center of his learning process.

This paper covers two main interests: scientific and pedagogical. The scientific interest consists in adding a psychological dimension to the ongoing functional one of English language teaching. The pedagogical interest for one lies not only on the sensitization of Gabonese youth (teaching them to do good around them) but also on the consideration of learners' centers of interest through Christmas, a feast they very much like.

Our approaches are intended to be communication-based, theme-based and moral-philosophical. A Christmas Carol presents many passages in the form of social issues and human values which can be used in classroom activities as topics for discussion to have an interactive classroom. These thematic aspects include intrinsic and extrinsic principles which will develop pupils' moral awareness.

Articles, Master's theses, books have served as a solid basis to the present study. As a related review of literature, the reader is cordially invited to consider the following researchers: In their book, Language, Literature and the Learner Creative Classroom 


\section{International Journal of Current Science Research and Review}

ISSN: 2581-8341

Volume 04 Issue 11 November 2021

DOI: 10.47191/ijcsrr/V4-i11-14, Impact Factor: 5.825

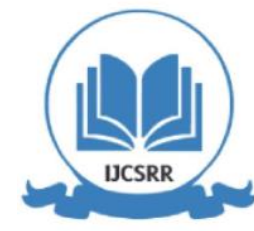

www.ijcsrr.org

Practice, Carter and McRae (1996) recommend using literary texts to help students go beyond the basic knowledge of the language. They believe that using literary excerpts to help develop the four skills (i.e., reading, listening, writing, listening, and speaking) and language areas (i.e., vocabulary, grammar, and pronunciation) is very popular within the field of foreign language acquisition and teaching nowadays. In addition, Junastri Elfina Siahaan (2010) from Sumatra Utara University defended a thesis entitled An Analysis of Moral Lesson in Charles Dickens' A Christmas Carol, where she sustains that a good and bad person's attitude are the standard norm of moral lesson in the society. In "Literature in EFL/ESL Classroom", Mohammad Khatib et al. (2011), make a review on how literature can be integrated as a didactic material in both EFL and ESL classrooms. Ursula Peggy Susanti's $A$ Study of Scrooge's Behavior Change as Seen in Charles Dicken's [Sic] A Christmas Carol (2018) analyses Scrooge's transformation throughout the novella. In her memoire entitled, Teaching English Through Some African Literary Texts to Improve Pupils' Language Acquisition: The case of the Second Cycle, Mareille Eyang (2020) explains that the use of African literary texts can help improve students' English language acquisition and develop learners' communicative skills.

This paper is articulated around three main sections. The first section evokes educational themes contained in the book; the second section proposes some activities to implement in the classroom; the third and last section deals with the research methodology and the analysis of data.

\section{Educational themes for value transmission and character construction}

The whole novella of A Christmas Carol is a parable, by that we mean a moral tale with a strong message grouping together a variety of themes. This section highlights educational themes such as kindness, family, redemption, which can be explored in the classroom.

\subsection{Generosity as an educational value}

Generosity constitutes a critical theme in Dickens's short novel. Indeed, as the book opens, Scrooge is presented to the reader as someone who has achieved worldly success but remains miserable, inflicting economic and human misery around him. He lives in seclusion and rejects all social intercourse. Scrooge is antipathic and not interested in changing his ways. Money is the sole thing that matters to Scrooge, which he never uses. On the matter, his nephew Fred is not wrong when he decries: "His wealth is of no use to him. He don't [Sic] do any good with it. He don't make himself comfortable with it." (Dickens, p. 57). Clearly, as a good capitalist, Scrooge compiles wealth, which he neither uses for himself, nor for others' sake.

An initially money-obsessed businessman, Ebenezer Scrooge learns that material success is hollow and unfulfilling without kindness towards his fellow creatures. When he learns his lesson from the three spirits (Ghost of Christmas Past, Ghost of Christmas Present and the Ghost of Christmas Yet to come), Scrooge becomes bountiful towards his employee, Bob Cratchit that he used to mistreat, and anonymously sends his family a Christmas turkey as illustrated in the following passage: "I'll send it to Bob Crutchit's! Whispered Scrooge, rubbing his hands, and splitting with a laugh. He sha'n't [sic] know who sends it (Dickens, p.79). Scrooge later promotes the same Bob Cratchit to be his partner in the business, so that he could have enough money to save his son Tiny Tim from dying a premature death. He graciously offers: "I'll raise your salary, and endeavour to assist your struggling family, and we will discuss your affairs this very afternoon, over a Christmas bowl of smoking bishop" (Dickens, p.83). Extremely memorable, Scrooge becomes far more generous in donating to charity houses. In using this excerpt from the novella for educational purpose, the Gabonese teacher of English will fully meet his/her teaching objectives since from a cardinal topic of that kind, pupils will be positively impacted. Corroboratively, asked about A Christmas Carol's impact on the reader, Charles Mackey stated the book's influential features on the reader. The text reads: "[A Christmas Carol] is a tale to make the reader laugh and cry-open his hands, and open his heart to charity even towards the uncharitable" (as cited in Kinser, 2010, p.11). Unquestionably, such an excerpt can change miser pupils into generous ones.

\subsection{Family and its importance}

The importance of family should be reminded to our Gabonese learners. Our children need to be educated that a cohesive and loving family provides firm bases to personal fulfilment. Coming back to the novella, it is well worth saying that the theme of family is used throughout 'A Christmas Carol to illustrate Scrooge's transformation from a malicious, misanthropic, and cold person to a philanthropic and caring one.

Dickens presents the importance of family and the unconditional support for one another through the dialogue between Scrooge and his nephew in stave I. As the book opens, Fred, Scrooge's dead sister's son, invites his uncle to dinner at Christmas 


\section{International Journal of Current Science Research and Review}

ISSN: 2581-8341

Volume 04 Issue 11 November 2021

DOI: 10.47191/ijcsrr/V4-i11-14, Impact Factor: 5.825

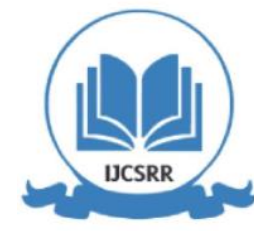

www.ijcsrr.org

that he considers as a "kind, forgiving, charitable, pleasant time" (Dickens, p. 12), but Scrooge rudely declines with a lugubrious "Good afternoon" (Dickens, pp. 12-13). Later in the novella, it is revealed that Fred believes Scrooge will change his mind. This persistence and unquestioning belief in his uncle, forestalls the underlying ideal of a family: no matter the circumstances, family will always protect and support one another. The theme of family and its importance is clearly evidenced in stave 5 when Scrooge eventually accepts his nephew's dinner invitation at Christmas. The narrator reveals: "In the afternoon he returned his steps towards his nephew's house. He passed the door a dozen times, before he had the courage to go up and knock. But he made a dash, and did it [...] It's I. your uncle Scrooge. I have come to dinner. Will you let me in, Fred? " (Dickens, p. 81). This decision from Scrooge to dinner at his nephew's makes him realize the supreme importance of family's love and unity in man's life. Therefore, Scrooge who was seen as the "Ogre of the [Cratchit] family" (Dickens, p. 53), will be transformed to a "second father to Tiny Tim" (Dickens, p. 83). In using the transformation of the gruesome Ogre to a paternal figure, Dickens demonstrates Scrooge's new self, who finally learns that "family provides the antidote to coldness" (LitCharts, 2014, p. 2). Accordingly, the Fezziwig family, the Cratchit family, as well as the Fred family represent comforting warmth in the novella, a tremendous wealth Scrooge did not possess before his transmutation.

\subsection{Opportunity for Redemption}

The opportunity for redemption is another educational theme of Dickens's A Christmas Carol. The author argues that one can atone for his/her mistakes if one truly desires to. Consequently, the road to repentance is open to everyone.

If across the course of his life, Scrooge has been pushed deeper and deeper into misanthropy, it happens that in stave 2, he is emotionally affected by his tour of his own past. He thus begins to regret his reprehensible demeanor with the boy singing a Christmas Carol. He tells the Ghost of Christmas Past: "There was a boy singing a Christmas Carol at my door last night. I should like to have given him something" (Dickens, p. 32). Scrooge also feels regret for his dismissive attitude towards his clerk Bob Cratchit. He instantly recognizes: "I should like to be able to say a word or two to my clerk just now" (Dickens, p. 37). The same pattern is repeated by the author concerning his negligence of Fred, not to mention his sadness as regards his then girlfriend Belle. Last but not the least, later in the novella, Scrooge expresses utter horror at the thought that Tiny Tim, Bob Cratchit's son, might die. Through these occurrences, Scrooge demonstrably manifests empathy, commiseration, and most significantly, genuine repentance for his misdeeds. He who used to think that the poor better die to "decrease the surplus population" (Dickens, p. 14) now hopes Tiny Tim will survive.

Following his pledge to do good around him, Scrooge seems relieved from a burden. He happily exults: "I am as light as a feather, I am as happy as an angel; I am as merry as a schoolboy. I am as giddy as a drunken man. A merry Christmas to everybody! A happy New Year to all the world! Hallo here! Whoop! Hallo! (Dickens, p. 78)”. Here, the author expertly shows that the old miser has died, and a new, happier, kinder Scrooge has emerged: Scrooge is reborn. As our audience covers a great number of young people who are susceptible to make mistakes in life, such a topic is mandatory to tell our pupils that it is never too late to do the right thing.

\section{Some Activities and Procedures to Teach $A$ Christmas Carol in the classroom}

Tell me, I forget. Show me, I remember. Involve me, I understand" (Xunzi Xun Kuang, 312-230 BC)

From the above quote, one can easily understand that the only way to develop learners' communicative skills and raise their moral awareness is to get them involved in activities of all kinds, which is feasible with our allegorical didactic source $A$ Christmas Carol.

Reading activities comprise reading comprehension, reading aloud task, partner oral reading. Listening activities cover tape script, song, live listening, story retelling through trailers. Speaking activities encompass discussion/debate, oral presentation, dialogue. Writing activities include dictation, error correction, essay. These activities are meant to put learners at the center of the learning process. However, for concision purposes, we are just going to present a few of them.

\subsection{Tape Script for Standard Pronunciation and Extensive Vocabulary}

The "tape script" is the written version of the words that learners hear when performing listening activities. The purpose of this tape script activity is to train the learner's ear, get him/her familiar with authentic pronunciation by native speakers and make him/her work his vocabulary level for a quick and fluent listening. The activity consists in listening a two-minutes recording using a short script. The script is a passage from A Christmas Carol with specific objectives. It presents some missing words or expressions that 


\section{International Journal of Current Science Research and Review}

ISSN: 2581-8341

Volume 04 Issue 11 November 2021

DOI: 10.47191/ijesrr/V4-i11-14, Impact Factor: 5.825

IJCSRR@ 2021

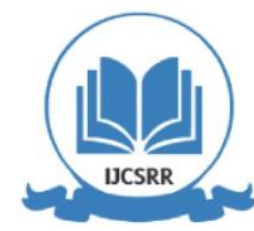

www.ijesrr.org

the students will have to fill while listening to the tape. The students are then given the script. The tape is played twice before the task for the students to go through the script and endeavour to catch the missing words. The third time, students are asked to complete blank spaces. From the tape script, the teacher can also conduct some other exercises such as comprehension questions.

\subsection{Christmas Song from the Book to Convey a Joyful Atmosphere}

Songs are a useful tool in language acquisition and adapted versions of A Christmas Carol are full of sweet songs linked to Christmas celebration. They can be used by the teacher to open or close his sessions, to announce the topic, to keep and change the tempo, to discover new words, and to revise language structures. However, some useful points should be kept in mind for a successful execution. First, the teacher should print the lyrics of the song for the learners. Second, learners listen to the song a for a certain amount of time and read while singing along. Students can simply sing along the song, but depending on their age and skills, the teacher can have a lyric video. For older learners, listening free of lyrics is a good way to challenge them. The selected song may be exploited in the form of a text if the teacher desires it.

\subsection{Story Retelling through Trailers}

As we all know, A Christmas Carol has been adapted in various forms in both the cinematic and educational domains. Such adapted aids are useful for English language learning seeing that they develop students' listening skill. The teacher needs a TV or a projector to facilitate the implementation of the activity. He/she divides the class into four groups, called A, B, C and D. Then, he/she plays the trailer of A Christmas Carol for a few minutes and the last time, the video plays in slow motion. Meanwhile, the students listen and watch the trailer at the same time for them to have clues. At the end, the teacher asks some questions such as: "What is the tittle?"; "What is the author's name?"; "What is the main character's name?"; "Where is the scene taking place?"; "What is the trailer about?", etc. The teacher expects each group to give an answer to every question and asks them to retell the whole story while highlighting the main theme in the trailer, which can lead to a debate.

\subsection{Role Play as an Enjoyable Activity to Boost Motivation}

Role play is a technique which can develop students' fluency in the target language. It promotes horizontal interaction in the classroom, increases motivation and makes the teaching-learning process enjoyable. This activity can be performed through scripted or unscripted role play. The teacher selects a short dialogue from A Christmas Carol and prepares the scenario. He chooses the roleplayers based on the number of characters in the script. Every student tries his/her best to emulate the characters in the book. The teacher may select Fred's conversation with Scrooge, specifically, when he comes to wish a merry Christmas to his uncle. This scenario for example needs a pair of pupils to be executed. However, the teacher can involve every pair in the activity alternately. Excerpts from Scrooge's dialogue with the four ghosts can also serve as role play material.

\subsection{Discussion / Debate on the Importance of Generosity or Compassion}

Discussion is an interesting activity that enables pupils to interact with their peers. It maximizes the amount of communicative and interactional practice between learners. It also motivates them to learn as they can express their ideas and opinions. As a result, learners gain confidence and fluency. Dealing with A Christmas Carol, discussion, in the class context, is generally raised out of a text or a passage from the book. After the study of the text, the teacher is always led to ask students some questions based on a particular theme or issue. Since the book is a moral tale, the main topic should revolve around a moral value such as generosity or compassion. Presented in the form of a question, the title of the text generally highlights the issue for discussion. The teacher must make sure that the questions are clear and easy for the debate or the discussion to be lively and constructive. The role of the teacher in a discussion session is critical. He facilitates and conducts the debate, help students be proactive. The teacher should also consider the heterogeneity of the classroom in considering students' diverse opinions. Topics for discussion may include: 'Do you think that having money makes happy?'; 'Do you ever give money or clothes to the poor?'; 'What do you think it would be like to work for someone like Scrooge'?

\subsection{Reading comprehension for Meaning Acquisition}

Extracting meaning from what one reads, is one of the main goals of reading. The process of comprehension is both interactive and strategic. Rather than passively reading the text, the learners must analyze it and make it their own. For the success of the operation, pupils need modeling, practice, and feedback. Questioning is one of the most used key comprehension strategies. Asking and answering questions about the text is a very common strategy used by teachers to help students focus on the meaning. In this 


\section{International Journal of Current Science Research and Review}

ISSN: 2581-8341

Volume 04 Issue 11 November 2021

DOI: 10.47191/ijcsrr/V4-i11-14, Impact Factor: 5.825

activity, students are expected to read carefully and entirely the text before they start answering questions. This is how the teacher can check if they have understood or not the text.

\section{Research Procedure and Result Analysis}

The methodology used in this study provides an understanding of how the research was conducted. This includes the environment and instrument used to obtain the data and the analysis of the results

\subsection{Data Collection Environment and Instrument}

The survey was conducted at Lycée Georges MABIGNATH, an urban state secondary school located in the Northeast Libreville. Two questionnaires were designed for the purpose of this research: One destined to eighty (40) second cycle pupils, and the other to ten (10) teachers of English. The main objective was to know what both categories thought of the introduction of $A$ Christmas Carol as an authentic source for language acquisition and moral value teaching in Gabonese schools. Therefore, we had encouraging results as shown in the next sections.

\subsection{Teachers' Questionnaire and Discussion}

The results of the teachers' questionnaire are presented as follows:

Question 1: What is your qualification? This question was necessary to acquire qualitative data. Teachers' profile at stake here. We noticed teachers had respectively, 20\% of CAPES (teachers teaching from first to upper sixth form), 60\% of CAPC (secondary school teachers), $10 \%$ of bachelor's degree (hired on service needs), and 10\% of master's degree (equally hired on service needs). This helped us to identify teachers who have received a training at Ecole Normale Supérieure and have forcibly received didactic and pedagogical training, and those who just have a faculty training, who have never received the theories, principles, methods, techniques, and procedures as regards English language teaching.

Question 2: How long have you been teaching English? This question was essential to know the experience of our audience. The results revealed that out of 10 teachers, $60 \%$ (6) had at least 10 years of experience; $20 \%$ (2) had four years of practice, and $20 \%$ (2) were newly recruited teachers (having one year' experience).

Question 3: Do you design clear objectives when you prepare your lesson? Here, the researchers enquired whether teachers insist only on the functional aspects of English language acquisition, or they target other aspects such as theme-oriented supports. $70 \%$ of teachers said that they employed thematic contents during their lessons. $20 \%$ said that they privileged language skills in lower classes. $10 \%$ of teachers, however, said that they combined both.

Question 4: What subjects do you often teach your pupils? a) Economics b) Politics c) Social d) Entertainment e) Other. On this question, a stressed was laid on the direction of the thematic content employed by the practitioners. The results resoundingly revealed that three areas were opted for: Politics (50\%), Social (40\%), and Economics (10\%). We frankly think that the social canon should be reinforced in so far as we live in a society in which children enormously need to be inculcated noble values. The book under study, A Christmas Carol can perfectly serve that purpose.

Question 5: What type of support do you often use? a) Texts b) Videos c) Audios d) Other. Unsurprisingly, the text was ranked first. $80 \%$ of teachers said that they liked texts for their practicability. While $20 \%$ informed that from now and then, they resorted to audios and videos. Some factors may explain such a reality. It appears that some classrooms lack electricity supply. Another key and deplorable factor is generational. Many experienced teachers do not use audios, videos, projectors, however, the youngest can. This state of fact should be reversed. Today's world is digital and technology oriented. Our android generation of young pupils will certainly be pleased if they listened to or watched a short sequence of A Christmas Carol in the classroom. This will change from routine and monotony. This will enable the acquisition of an authentic pronunciation.

Question 6: What is the impact of your activities on learners? A great number of teachers (90\%) said that their learners felt motivated when it came to activities. The reason for such a keen interest is that teachers of English in Gabon are adamant that a teacher must elaborate engaging and interactional activities to face English as a Foreign Language teaching challenges. $10 \%$ of teachers sustained that the positive impact was much felt in morning classes. Afternoon classes are not so successful. Pupils feel tired, hungry, asleep. Question 7: Have you ever used a literary content as a didactic support? If so, which literature was it? This question was satisfactorily answered by the teachers. $100 \%$ confirmed to have used it in their classes. This question was profound in that learning 


\section{International Journal of Current Science Research and Review}

ISSN: 2581-8341

Volume 04 Issue 11 November 2021

DOI: 10.47191/ijcsrr/V4-i11-14, Impact Factor: 5.825

a language out of its literature is extremely detrimental. Teachers continue with the use of literary contents in their teaching to make their learners in contact with some specificities of the English language.

Question 8: Have you ever read A Christmas Carol by Charles Dickens? This question was about asking the teachers whether they had read the book. We realized that all the 10 teachers (70\%) had read the book, whereas $40 \%$ had not but knew that the novella was by Charles Dickens. Understandably, seeing that as trainees, teachers are taught three (3) kinds of literatures (American, British, and African Anglophone), many are also influenced by the other forms of literature. This is normal. Nevertheless, we urge those who have not perused it yet to do it. They will discover how pedagogically and philosophically rich it is.

Question 9: Using A Christmas Carol to teach English to learners would be: a) Interesting b) boring c)risky? Justify. 'Interesting' $(100 \%)$ was overpoweringly reported in the questionnaires. The audience think that the book can be implemented in the English syllabus and used as an authentic didactic material in class because the content is teachable and can help to reach the goal in the teaching of moral education.

\subsection{Pupils' Questionnaire and Discussion}

As regards the pupils' questionnaire, the results are shown as follows:

Question 1: How long have you been learning English? This question provides the reader with information on how long the learners have been learning the English language. We discovered that the great majority $(90 \%)$ had spent at least 5 years of English learning. Thus, the audience is acquainted with the English language. 10\% represented the percentage of students who had less than 5 years in English learning. That situation is comprehensible in a country where 8,000 teachers are required to fill the gap in our educational system (Lyonnel Mbeng Essone, Gabonmediatime, 2021).

Question 2: What is your level in English? This question was critical to our study because we wanted to know the level of our learners. The facts spoke for themselves: $70 \%$ revealed that were unable to speak, listen, write, or even read English properly. We suspect that being in an EFL context, learners are heavily influenced by French and other local dialects (Nzebi, Fang, Téké, Kota, Punu, etc.). That is why teachers should find innovative, successful, and viable strategies to challenge that overbearing influence. $20 \%$ responded that they had an intermediate level, when $10 \%$ claimed to have an advanced level. The previous learners come from Arts oriented classes. It is undeniable that they are language skilled.

Question 3: Do you roleplay in the classroom? This question helped to have a gist of the activities conducted in class by teachers of English in our country. Unanimously, pupils responded 'yes'. It is common knowledge that a modern language class should be vivid. It should be electric. Role play for example, helps shier learners and inspires better career choices at learners.

Question 4: What are the most evoked themes by the teacher? Drugs (60\%) and teenage (30\%) pregnancies were mostly recorded for this question. 10\% encompassed other themes such as environment, politics, economics... From the above results, one can observe that teachers have already commenced the moralization of pupils. A Christmas Carol will be a supplement to their cause, given that literature is the mirror up to nature, the world in miniature. In learning from Scrooge's mistakes, learners will develop positive values, which will make them better people in the future.

Question 5: What are the most used supports by the teacher? Texts, videos, audios? Pupils confirmed their teachers' answer: the text $(100 \%)$. Teachers should also explore audios and videos because their learners are much interested when they are taught via technological tools. The teacher may target a specific activity to integrate those materials and motivation will follow.

Question 6: How much do you like stories with a moral lesson at the end? Justify. Whereas 10\% said they disliked such stories because some of them have a sad ending, $90 \%$ appreciated because they serve as pieces of advice. An allegory (a story with a fixed and symbolic meaning), A Christmas Carol will be of great help to our youth, especially while some are shown on social media for serious misconduct.

Question 7: What do you think of miserliness? Thematically related to A Christmas Carol, this question served to obtain learners viewpoints on one of the main topics in the novella. Happily, learners (100\%) thought it was a bad thing. In the same benevolent logic, we intend to remind the value of sharing to our learners.

Question 8: Do you like Christmas? Thematically linked to our novella, this question bears considerable relevance. Moreover, it tackles learners' centres of interest. Unsurprisingly, $100 \%$ of the learners said 'yes'. Their straightforward answer reinforces our idea to integrate the novella in the teaching of English.

Question 8: Will you be happy to learn English through A Christmas Carol by Charles Dickens? Because they had no idea of the book and its author, we endeavoured to tell them that is an English novella that criticizes the miserliness of the rich and talks about 


\section{International Journal of Current Science Research and Review}

ISSN: 2581-8341

Volume 04 Issue 11 November 2021

DOI: 10.47191/ijcsrr/V4-i11-14, Impact Factor: 5.825

IJCSRR @ 2021

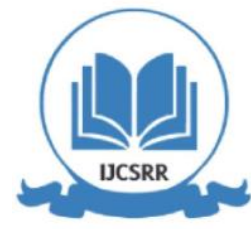

www.ijcsrr.org

Christmas. From that moment, learners answered favourably to the question. Wonderfully, 100\% approved. This open, clear, and fundamental question strikingly demonstrates learners' keen desire to give our novella a try. It also underscores their sense of social justice and their appreciation of Christmas celebration.

\section{CONCLUSION}

In a nutshell, the process of language acquisition is a multi-faced process which implies not only the development of the communicative competence among the pupils, but also the construction of pupils' personality. We have just had the opportunity to grasp it through Charles Dickens's A Christmas Carol. From the rich topics the book contains, the activities that can be conducted around it, one optimistically thinks that its use by teachers will build learners' motivation. More importantly, our results reveal that both pupils (100\%) and teachers (100\%) are interested in the use of A Christmas Carol in their teaching and learning processes.

\section{REFERENCES}

1. A Christmas Carol. (2014). LitCharts. LitCharts LLC. Www.LitCharts.com.

2. Carter, Ronald \& Mcrae, John. (1996). Literature, Language, and the Learner: Creative Classroom Practice. New-York: Pearson Education Limited.

3. Dickens, Charles. (2009). A Christmas Carol and Other Christmas Books. Robert Douglas Fairhurst (Ed.), United States: Oxford World's Classics.

4. Eyang, Mareille (2020). Teaching English through some African literary texts to improve pupils' language acquisition: the case of the second cycle. Mémoire de Master. École Normale Supérieure, Libreville.

5. Kelly, Joseph F. (2004). The Origins of Christmas and the Feast of Christmas. Collegeville, Liturgical Press.

6. Khatib, Mohammad. (2011). Literature in EFL/ESL Classroom. Canadian Center of Science and Education, Vol.4, N ${ }^{\circ} 1$. 201-2018, ISSN 1916-4742 E-ISSN 1916-4750. www.ccsenet.org/elt.

7. Lohse, Josh. (2010). Great Expectations: The Contemporary Reception of Charles Dickens's A Christmas Carol. In Brent E. Kinser (Ed), Essays on Charles Dickens's A Christmas Carol (pp. 9-14). Western California University. Cullowhee : Coulter Press.

8. Mbeng Essone, L. (2021). Gabon : le Gouvernement à la Recherche de 8000 Enseignants à la Veille de la Rentrée. Gabonmediatime. Libreville, Gabon. Accessed 07 November 2021.

9. Siahaan, Junastri Elfina R. (2010). An Analysis of Moral Lesson in Charles Dickens' A Christmas Carol. Medan: University of Sumatra Utara. Reg.No:060705019.

10. Sunarsasi, Susana. (2020). The Cold-and Closed-Heart Character of Ebenezer Scrooge, the Main Character in Charles Dickens. Yogyakarta: Sanata Dharma University.

11. Susanti, Peggy U. (2018). A Study of Scrooge's Behavior as Seen in Charles Dicken's A Christmas Carol. Yogyakarta: Sanata Dharma University.

Cite this Article: Ralph OBANDJA BOYO (2021). A Christmas Carol by Charles Dickens: An Authentic Didactic Source for English Language Acquisition and Moral Value Teaching. International Journal of Current Science Research and Review, 4(11), 1585-1591 